\title{
Analisis Perbedaan Manajemen Laba Sebelum dan Sesudah Penerapan PSAK Konvergensi IFRS
}

\author{
Sarlina Sari \\ Universitas Bina Sarana Informatika \\ e-mail: sarlinasari.new@gmail.com
}

(Srlina Sari, 2019)

Sarlina Sari. (2019). Analisis Perbedaan Manajemen Laba Sebelum dan Sesudah Penerapan PSAK Konvergensi IFRS. Moneter, 6(1), 13-22.

\begin{abstract}
This study aims to examine and analyze whether earnings management after the implementation of SFAS convergence with IFRS is lower than earnings management prior to implementation of SFAS convergence with IFRS on top leadings in market capitalization companies listed on BEI (Indonesia Stock Exchange) in period of 2010-2011. Earnings management is measured by absolute discretionary accruals using Modified Jones Model developed by (Dechow P., Sloan R., 1995). This study is hypothesis testing research.The population in this study are all companies included "50 top leadings in market capitalization" that listed on BEI. This study uses census and there were 10 companies fulfilling the population criteria. The type of data used are secondary data from company's financial statements obtained from BEI's official website. Data were analyzed by comparing average value of discretionary accruals before and after the implementation of SFAS convergence with IFRS.This result indicates that earnings management after the implementation of SFAS convergence with IFRS is lower than earnings management prior to implementation of SFAS convergence with IFRS on top leadings in market capitalization companies listed on BEI in period of 2010-2011.
\end{abstract}

Keywords: Earnings management, discretionary accruals, SFAS convergence with IFRS

\section{PENDAHULUAN}

Suatu perusahaan didanai oleh investor dan dikelola oleh manajemen. Manajer mempertanggungjawabkan seluruh transaksi dan peristiwa ekonomi yang terjadi di dalam perusahaan yang dikelolanya melalui laporan keuangan. (Kieso, D. E., J. J. Weygandt, 2008) menyatakan bahwa laporan keuangan merupakan sarana utama yang digunakan manajemen untuk mengkomunikasikan informasi keuangan kepada pihak di luar perusahaan. Salah satu parameter penting dalam laporan keuangan yang digunakan untuk mengukur kinerja manajemen adalah laba.

Menurut SFAC (Statement of Financial Accounting Concepts) No. 1 tahun 1978, informasi laba merupakan perhatian utama untuk menaksir kinerja atau pertanggungjawaban manajemen. Selain itu informasi laba mempermudah pemilik atau pihak lain dalam menaksir earnings power perusahaan di masa yang akan datang. Adanya kecenderungan lebih memperhatikan laba ini disadari oleh manajemen, khususnya manajer yang kinerjanya diukur berdasarkan informasi tersebut, sehingga mendorong timbulnya praktik manajemen laba (Widyaningdyah, 2001).

(Nugroho, 2011) menyatakan sebagai berikut:

"Manajemen laba bukanlah hal baru dalam khasanah dunia akuntansi keuangan. Istilah manajemen laba telah menjadi sebuah fenomena yang telah turut menambah wacana perkembangan teori akuntansi dan merupakan salah satu kajian yang menarik dalam riset akuntansi. Istilah manajemen laba muncul sebagai konsekuensi langsung dari upaya-upaya manajer atau pembuat laporan keuangan untuk melakukan manajemen informasi akuntansi, khususnya laba (earnings), demi kepentingan pribadi dan/atau perusahaan. Manajemen laba diduga muncul atau dilakukan oleh manajer atau para pembuat laporan keuangan dalam proses pelaporan keuangan suatu organisasi karena mereka mengharapkan suatu manfaat dari tindakan yang dilakukan".

Menurut (Scott, 2006) seorang manajer akan memilih satu metode atau kebijakan tertentu yang diperbolehkan GAAP (General Accepted Accounting Principles) dengan harapan dapat memaksimumkan utility mereka atau meningkatkan nilai perusahaan. Manajer mempengaruhi angka laba sistematis dengan cara memilih kebijakan dan prosedur akuntansi tertentu yang bertujuan untuk memaksimumkan utility manajer dan harga saham. Perilaku demikian disebut sebagai manajemen laba. Manajemen laba juga dapat diartikan sebagai cara akuntansi yang dilakukan oleh manajer dengan memanfaatkan fleksibilitas dalam menyusun laporan keuangan untuk memenuhi target laba (Levitt, 1998)).

(Fischer, M., 1995) secara spesifik berpendapat bahwa manajemen laba adalah tindakan manajer 
untuk meningkatkan atau menurunkan laporan laba suatu perusahaan tanpa sebenarnya terjadi kenaikan atau penurunan dari profitabilitas jangka panjang perusahaan.

Manajemen laba menjadi penting untuk diteliti karena dapat memberikan gambaran akan perilaku manajer dalam menyajikan laporan keuangan perusahaan pada periode tertentu, yaitu adanya kemungkinan munculnya motivasi tertentu yang membuat mereka "bermain" dengan data keuangan yang dilaporkan. Manajemen laba menjadi tidak selalu harus dikaitkan dengan upaya untuk memanipulasi data atau informasi akuntansi tetapi dapat juga dikaitkan dengan pemilihan metode akuntansi (accounting methods) untuk mengatur keuntungan yang bisa dilakukan (Nugroho, 2011).

Tindakan manajemen laba telah memunculkan beberapa skandal pelaporan akuntansi yang secara luas diketahui, antara lain Enron, Merck, WorldCom, dan mayoritas perusahaan lain di Amerika Serikat. Skandal Enron dan WordCom sepanjang tahun 2002 merekayasa laporan keuangannya sehingga menjadi overstated, menyesatkan dan membingungkan. Muaranya ialah pada angka laba rugi yang dimanage, lalu secara otomatis mempengaruhi harga saham, selanjutnya kemerosotan kepercayaan masyarakat, dan berakhir pada kebangkrutan. Peristiwa tersebut telah menempatkan kepercayaan publik terhadap laporan keuangan semakin rendah (Avianti, 2006).

Bapepam (2004) dalam (Avianti, 2006) menyatakan sebagai berikut:

"Kecurangan akuntansi juga terdapat di Bursa Efek Jakarta (sekarang BEI), antara lain kasus PT. Kimia Farma Tbk., dan PT. Lippo Tbk., pada tahun 2002 yang mengindikasikan adanya praktik manajemen laba. PT. Kimia Farma Tbk., pada tahun 2002 menaikkan laba hingga Rp 32,7 Milyar. Manajemen laba tersebut diduga terkait dengan keinginan manajemen lama untuk dipilih kembali oleh pemerintah guna mengelola perusahaan farmasi tersebut. PT. Indo Farma Tbk., pada tahun 2004 melakukan praktik manajemen laba dengan menyajikan overstated laba bersih senilai Rp 28,870 Milyar, sebagai dampak dari persediaan barang dalam proses yang lebih tinggi dari yang seharusnya, sehingga harga pokok penjualan tahun tersebut understated".

Praktik manajemen laba pada perusahaan dipicu oleh keinginan manajemen untuk memanfaatkan kelonggaran standar akuntansi lokal atau PSAK (Pernyataan Standar Akuntansi Keuangan) yang mengizinkan pemilihan metode dan kebijakan akuntansi yang diinginkan manajemen untuk diterapkan secara konsisten. Hal ini menyebabkan output dari proses akuntansi berbagai perusahaan menjadi berbeda, sehingga rentan terjadi praktik manajemen laba. Oleh karena itu, diperlukan standar akuntansi yang berlaku secara global agar kualitas informasi akuntansi yang disajikan manajemen meningkat dan seragam meskipun perusahaan beroperasi di negara yang berbeda.

Menurut (Rudra \& A, 2012), isu mengenai manajemen laba menjadi fokus tersendiri atas reliabilitas laporan keuangan yang dipublikasikan oleh perusahaan publik. Beberapa penelitian di negara-negara maju menyatakan bahwa standar akuntansi internasional/ IFRS (International Financial Accounting Standards) mampu meningkatkan nilai informasi akuntansi. Sebaliknya, juga terdapat beberapa penelitian bahwa IFRS pada pasar berkembang (emerging market) belum mampu menurunkan aktivitas manajemen laba.

(Rudra \& A, 2012) melakukan penelitian di India yang bertujuan untuk menguji apakah perusahaan yang mengadopsi IFRS dapat menurunkan praktik manajemen laba dibandingkan dengan perusahaan yang mengadopsi standar akuntansi lokal. Temuan mereka menunjukkkan bahwa perusahaan yang mengadopsi IFRS lebih suka melakukan praktik manajemen laba dibandingkan perusahaan yang tidak mengadopsi IFRS. Hal ini dapat menjadi bahan evaluasi bagi regulator pembuat standar akuntansi mengenai keefektifan pengadopsian IFRS dalam menurunkan praktik manajemen laba oleh perusahaan di negara bersangkutan.

Selain itu, (Gontcharov, I., 2007) menguji apakah terdapat perbedaan tingkat manajemen laba akunakun konsolidasian perusahaan publik Jerman yang disusun berdasarkan tiga standar akuntansi yang berbeda yaitu German GAAP, IAS (International Accounting Standards), dan US GAAP. Mereka menemukan bahwa tingkat manajemen laba perusahaan yang menyusun laporan keuangannya sesuai US GAAP secara signifikan lebih rendah, sedangkan tingkat manajemen laba berdasarkan German GAAP dan IAS cenderung sama. Berdasarkan bukti tersebut, mereka menyimpulkan bahwa pemilihan standar akuntansi yang berbeda dapat mempengaruhi manajemen laba.

(Lantto, 2007) juga meneliti apakah IFRS dapat meningkatkan kegunaan informasi akuntansi di Finlandia dengan melakukan survei pada manajer, analis laporan keuangan, dan auditor. Hasil penelitian tersebut menyatakan bahwa baik auditor, manajer, dan analis berpendapat bahwa laporan keuangan yang disusun berdasarkan IFRS dapat diandalkan dan relevan.

Berdasarkan beberapa hasil penelitian tersebut dapat disimpulkan bahwa standar akuntansi yang berkualitas sangat penting untuk pengembangan 
kualitas struktur pelaporan keuangan global, sehingga dapat menurunkan aktivitas manajemen laba oleh perusahaan. Standar akuntansi yang berkualitas terdiri dari prinsip-prinsip komprehensif yang netral, konsisten, sebanding, relevan, dan dapat diandalkan yang berguna bagi investor, kreditor, dan pihak lain untuk membuat keputusan alokasi modal (SEC, 2000 dalam (Chariri, Anis, 2010) Permasalahan akan kebutuhan standar yang berkualitas tersebut menuntun akan pengadopsian IFRS yang berdasar atas adanya peningkatan kualitas akuntansi dan keseragaman standar internasional.

Penerapan IFRS sebagai standar internasional menyebabkan semakin sedikitnya pilihan-pilihan metode dan kebijakan akuntansi yang dapat diterapkan perusahaan, sehingga akan meminimalisir praktik-praktik kecurangan akuntansi seperti manajemen laba (Prihadi, 2011:4 dalam (Rohaeni, D., 2012). Hal ini dibuktikan oleh beberapa hasil penelitian yang menunjukkan bahwa pengadopsian IFRS umumnya mampu meningkatkan kualitas standar akuntansi di sebagian besar negara, yaitu penelitian (C. Leuz \& Verrecchia, 2000); Ashbaugh dan Pincus (2001); (Christian Leuz, 2003); (Barth, M. E., W. R. Landsman, 2008); dan Christensen, Lee, dan Walker (2008).

\section{IFRS (International Financial Reporting Standards)}

IFRS merupakan standar akuntansi internasional yang diterbitkan oleh IASB (International Accounting Standar Board). Standar Akuntansi Internasional disusun oleh empat organisasi utama dunia yaitu Badan Standar Akuntansi Internasional (IASB), Komisi Masyarakat Eropa (EC), Organisasi Internasional Pasar Modal (IOSOC), dan Federasi Akuntansi Internasional (IFAC). IASB yang dahulu bernama IASC (International Accounting Standar Committee) merupakan lembaga independen untuk menyusun standar akuntansi. Organisasi ini memiliki tujuan untuk mengembangkan dan mendorong penggunaan standar akuntansi global yang berkualitas tinggi, dapat dipahami, dan dapat diperbandingkan (Choi et al., 1999 dalam (Situmorang, 2011) .

Sebagian besar standar yang menjadi bagian dari IFRS sebelumnya merupakan IAS. IAS diterbitkan antara tahun 1973 sampai dengan 2001 oleh IASC. Pada bulan April 2001, IASB mengadopsi seluruh IAS dan melanjutkan pengembangan standar yang dilakukan.

Perbedaan utama standar internasional ini dengan standar yang berlaku di Indonesia terletak pada penerapan revaluation model, yaitu kemungkinan penilaian aset menggunakan nilai wajar, sehingga laporan keuangan disajikan dengan basis "true and fair” (IFRS framework paragraf 46). Mengadopsi
IFRS berarti menggunakan bahasa pelaporan keuangan global, yang akan membuat perusahaan bisa dimengerti oleh pasar dunia (Situmorang, 2011).

\section{Manajemen Laba}

Para pakar kurang seragam dalam mendefinisikan manajemen laba. (Schipper, 1989) mendefinisikan manajemen laba sebagai suatu intervensi dengan maksud tertentu terhadap proses pelaporan keuangan eksternal dengan sengaja untuk memperoleh beberapa keuntungan pribadi. (Scott, 2006) menyatakan bahwa pilihan kebijakan akuntansi oleh manajer untuk suatu tujuan tertentu disebut manajemen laba. Manajemen laba juga dapat didefinisikan sebagai "some ability to increase or decrease reported net income at will" (Copeland, 1968). Ini berarti bahwa manajemen laba merupakan usaha manajemen untuk memaksimalkan, atau meminimalkan laba, termasuk perataan laba sesuai dengan keinginan manajemen.

Sugiri (1998) dalam (Widyaningdyah, 2001) membagi definisi manajemen laba menjadi dua, yaitu: "Definisi sempit: Manajemen laba dalam hal ini hanya berkaitan dengan pemilihan metode akuntansi. Manajemen laba dalam artian sempit ini didefinisikan sebagai perilaku manajer untuk "bermain" dengan komponen discretionary accruals dalam menentukan besarnya laba.

Definisi luas: Manajemen laba merupakan tindakan manajer untuk meningkatkan (mengurangi) laba yang dilaporkan saat ini atas suatu unit dimana manajer bertanggung jawab, tanpa mengakibatkan peningkatan (penurunan) profitabilitas ekonomis jangka panjang unit tersebut”.

(Healy, 1985) menjelaskan bahwa:

"Terdapat beberapa cara yang digunakan oleh manajemen untuk melakukan manajemen laba, salah satu cara adalah dengan mengendalikan transaksi akrual. Transaksi akrual adalah transaksi yang tidak mempengaruhi aliran kas masuk maupun kas keluar. Misalnya pengakuan hutang, biaya atau piutang/pendapatan. Transaksi akrual terdiri dari transaksi yang bersifat non-discretionary (bukan mengubah kebijakan atau metode akuntansi) dan yang bersifat discretionary. Transaksi yang bersifat non-discretionary yaitu transaksi yang dicatat dengan menggunakan satu prosedur apabila prosedur tersebut dipilih, maka manajemen diharapkan konsisten dalam menggunakan prosedur tersebut. Contoh dari transaksi akrual yang non-discretionary adalah metode depresiasi, penggunaan metode akuntansi dalam perusahaan minyak antara full method dan successful effort, metode penentuan harga pokok persediaan FIFO (First in First Out) dan LIFO (Last in Firt Out). Transaksi akrual yang discretionary memberikan kebebasan kepada manajemen menentukan jumlah transaksi akrual secara fleksibel. 
Contoh yang termasuk transaksi ini adalah penentuan cadangan kerugian piutang yang nantinya akan menaikkan piutang dagang netto, menaikkan persediaan, menurunkan hutang dagang, dan hutang akrual (Scott, 2006)

Secara garis besar (Healy, 1985) menyatakan bahwa penggunaan transaksi discretionary accruals, manajemen dapat mempengaruhi laba dengan mengendalikan jumlah transaksi akuntansi. Contoh transaksi discretionary accruals yaitu menaksir jumlah piutang tidak tertagih diturunkan dari tahun sebelumnya, sehingga jumlah piutang netto akan naik, dengan asumsi pendapatan tetap, maka laba tahun ini akan relatif tinggi. Selain itu adanya perubahan taksiran umur ekonomis aset tetap atau amortisasi aset tidak berwujud. Proses yang dilakukan oleh manajemen tersebut dengan cara menggeser periode biaya atau pendapatan, sehingga manajemen dapat memperoleh keuntungan dibalik perubahan yang dilakukannya (Lestari, 2010)

\section{Kerangka Pemikiran}

Standar akuntansi mengatur kebijakan akuntansi secara fleksibel. Fleksibelitas untuk memilih metode dan kebijakan akuntansi terkadang memotivasi manajer untuk meningkatkan, menurunkan atau meratakan laba dari tahun ke tahun. Laba merupakan salah satu informasi potensial yang terkandung di dalam laporan keuangan dan sangat penting bagi pihak internal maupun pihak eksternal perusahaan. Perhatian para investor yang terpusat pada informasi laba membuat manajemen berpotensi untuk melakukan manajemen laba.

Pengadopsian IFRS memiliki pengaruh yang sangat besar pada perusahaan, khususnya pada pelaporan keuangan perusahaan dan kinerja perusahaan. Pengadopsian standar akuntansi internasional ke dalam standar akuntansi domestik bertujuan menghasilkan laporan keuangan yang memiliki tingkat kredibilitas tinggi. Persyaratan akan item-item pengungkapan akan semakin tinggi sehingga nilai perusahaan akan semakin tinggi pula (Situmorang, 2011:2). Manajemen akan memiliki tingkat akuntabilitas tinggi dalam menjalankan perusahaan, laporan keuangan perusahaan menghasilkan informasi yang lebih relevan dan akurat, dan laporan keuangan akan lebih dapat diperbandingkan serta menghasilkan informasi yang valid untuk aset, hutang, ekuitas, pendapatan, dan beban perusahaan (Petreski, 2006).

Penerapan IFRS sebagai standar global akan berdampak pada semakin sedikitnya pilihan-pilihan metode akuntansi yang dapat diterapkan sehingga akan meminimalisir praktik-praktik kecurangan akuntansi seperti manajemen laba (Prihadi, 2011:4 dalam (Rohaeni, D., 2012). Sebelumnya telah ada beberapa hasil penelitian yang menunjukkan bahwa pengadopsian IFRS umumnya mampu meningkatkan kualitas standar akuntansi di sebagian besar negara, yaitu penelitian (C. Leuz \& Verrecchia, 2000); Ashbaugh dan Pincus (2001); (Christian Leuz, 2003); (Barth, M. E., W. R. Landsman, 2008); dan Christensen, Lee, dan Walker (2008).

PSAK dan IFRS memiliki perbedaan yang besar, PSAK Indonesia mengizinkan praktik akuntansi yang fleksibel, yang mana dapat disebut sebagai upaya akuntansi kreatif (manajemen laba). Diharapkan bahwa IFRS secara khusus akan membatasi praktik ini. Hasilnya, pelaksanaannya akan meningkatkan kualitas informasi akuntansi (Situmorang, 2011). Beberapa penelitian telah dilakukan untuk meneliti manajemen laba sebelum dan sesudah diadopsinya IFRS baik secara sukarela maupun diwajibkan.

Hasil penelitian (Daske, H., 2006) menyatakan bahwa pengadopsian IFRS dapat meningkatkan kualitas laporan keuangan. (Barth, M. E., W. R. Landsman, 2008) juga meneliti kualitas akuntansi sebelum dan sesudah dikenalkannya IAS/IFRS dengan menggunakan sampel sebanyak 327 perusahaan di 21 negara yang telah mengadopsi IAS secara sukarela antara tahun 1994 dan 2003. Dalam penelitian mereka ditemukan bukti bahwa setelah diperkenalkannya IFRS, tingkat manajemen laba menjadi lebih rendah, relevansi nilai menjadi lebih tinggi, dan pengakuan kerugian menjadi semakin tepat waktu, dibandingkan dengan masa sebelum transisi di mana akuntansi masih berdasarkan local GAAP. (Lantto, 2007) juga mengatakan bahwa laporan keuangan perusahaan publik Finlandia yang disusun berdasarkan IFRS dapat diandalkan dan relevan.

Hasil yang berbeda ditemukan oleh (Rudra \& A, 2012) yang melakukan penelitian di India dengan tujuan untuk menguji apakah perusahaan yang mengadopsi IFRS dapat menurunkan praktik manajemen laba dibandingkan perusahaan yang mengadopsi standar akuntansi lokal. Temuan mereka menunjukkan bahwa perusahaan yang mengadopsi IFRS lebih suka melakukan praktik manajemen laba dibandingkan perusahaan yang tidak mengadopsi IFRS. Selain itu, (Jeanjean, T., 2008) juga meneliti dampak keharusan mengadopsi IFRS terhadap manajemen laba dengan mengobservasi 1146 perusahaan dari Australia, Prancis, dan UK mulai tahun 2005 hingga 2006. Penelitian tersebut menemukan bukti bahwa manajemen laba di negaranegara tersebut tidak mengalami penurunan setelah adanya keharusan mengadopsi IFRS, dan bahkan meningkat untuk Prancis.

\section{Hipotesis}

Berdasarkan kerangka pemikiran yang telah diuraikan sebelumnya, hipotesis penelitian ini adalah manajemen laba sesudah penerapan IFRS lebih 
rendah dibandingkan dengan manajemen laba sebelum penerapan IFRS pada perusahaan top leadings in market capitalization yang terdaftar di Bursa Efek Indonesia tahun 2010-2011.

\section{METODOLOGI PENELITIAN}

\section{Desain Penelitian}

Penelitian ini adalah penelitian yang bertujuan untuk menguji dan menganalisis apakah manajemen laba sesudah penerapan PSAK konvergensi IFRS lebih rendah dibandingkan dengan manajemen laba sebelum penerapan PSAK konvergensi IFRS pada perusahaan top leadings in market capitalization yang terdaftar di Bursa Efek Indonesia tahun 20102011 melalui pengujian hipotesis. Sesuai dengan tujuan penelitian, maka jenis penelitian ini termasuk penelitian pengujian hipotesis. Metode yang digunakan dalam penelitian ini adalah metode komparatif. Dengan menggunakan metode komparatif peneliti membandingkan manajemen laba sebelum dan sesudah penerapan PSAK konvergensi IFRS.

Situasi studi penelitian tidak diatur. Unit analisis dalam penelitian ini adalah tingkat industri, yaitu perusahaan-perusahaan yang terdaftar di Bursa Efek Indonesia yang termasuk "50 top leadings in market capitalization". Intervensi peneliti adalah intervensi minimal. Horizon waktu penelitian ini adalah crosssectional, yaitu studi dilakukan untuk mengetahui hubungan komparatif beberapa subjek penelitian. Studi cross-sectional umumnya merupakan tipe studi satu tahap yang datanya berupa beberapa subjek pada waktu tertentu (Lastansi, 2008)

\section{Populasi Penelitian}

Populasi penelitian adalah perusahaan yang terdaftar di BEI (Bursa Efek Indonesia) yang termasuk "50 top leadings in market capitalization". Penelitian sebelumnya menggunakan sampel perusahaan yang memiliki total kapitalisasi pasar lebih dari 90 persen, sehingga unit analisis dalam penelitian ini dipilih perusahaan yang termasuk katagori " 50 top leadings in market capitalization" yang memiliki kapitalisasi pasar yang besar pula (per Maret 2010-2011). Kapitalisasi pasar merupakan nilai sebuah perusahaan berdasarkan perhitungan harga pasar saham dikalikan dengan jumlah saham yang beredar (Rusmanto, 2011).

\section{Operasionalisasi Variabel}

Dalam penelitian ini hanya terdapat satu variabel yaitu manajemen laba. Manajemen laba dapat diukur menggunakan discretionary accruals yang dihitung dengan cara menyelisihkan total accruals dan nondiscretionary accruals. Untuk menghitung discretionary accruals, digunakan Modified Jones Model yang dikembangkan oleh (Dechow P., Sloan
R., 1995). Model perhitungannya sebagai berikut:

TACCit $=$ Nit - OCFit

TACCit/TAi,t $-1=(1 / T A i, t-1)+\beta 1((\Delta R E V i t-$

$\triangle R E C i t) / T A i, t-1)+\beta 2(P P E i t / T A i, t-1)+$

it......

Berdasarkan persamaan (1), NADCC dapat dihitung dengan memasukkan kembali koefisien-koefisien:

$$
\begin{aligned}
& \text { NDACCit }=(1 / T A i, t-1)+\beta 1((\Delta \text { REVit }- \\
& \triangle \text { RECit }) / T A i, t-1)+\beta 2(\text { PPEit } / \text { TAi,t-1) + } \\
& \text { it..... } \\
& \text { DACCit = }(\text { TACCit/TAi,t-1) - } \\
& \text { NDACCit......... }
\end{aligned}
$$

TACCit : Total Accruals perusahaan i pada periode $\mathrm{t}$

NI : Net Income perusahaan i pada periode $\mathrm{t}$

OCFit : Operating Cash Flow perusahaan i pada periode $\mathrm{t}$

TAi,t-1 : Total Aset perusahaan i pada periode $\mathrm{t}-1$

$\triangle \mathrm{REVit}:$ Revenue perusahaan i pada periode $\mathrm{t}$ kurang revenue periode $\mathrm{t}-1$

$\triangle$ RECit : Receivable perusahaan $\mathrm{i}$ pada periode $t$ kurang receivable periode $\mathrm{t}-1$

PPEit : Nilai aset tetap (gross) perusahaan i pada periode $\mathrm{t}$

\section{Metode Analisis dan Rancangan Pengujian Hipotesis}

a. Metode Analisis

Dalam pengolahan data peneliti menggunakan alat bantu berupa perangkat lunak statistik (statistic software) yang dikenal dengan SPSS Ver. 20, sedangkan teknik analisis yang digunakan meliputi: statistik deskriptif dan uji beda rata-rata berpasangan. Berhubung penelitian ini menggunakan metode sensus tidak dilakukan uji signifikansi. Kesimpulan langsung diambil dari nilai rata-rata populasi sasaran $(\mu)$.

Untuk lebih jelasnya, berikut tahap-tahap perhitungan nilai rata-rata discretionary accruals masing-masing populasi sasaran $(\mu 1$ dan $\mu 2)$.

1) Menghitung nilai total accruals dengan cara menghitung selisih laba bersih dengan arus kas operasi. Nilai total accruals dijadikan sebagai variabel dependen. Kemudian dilakukan regresi untuk menentukan nilai non-discretionary accruals menggunakan model persamaan regresi berganda berikut:

TACCit/TAi,t-1 $=(1 /$ TAi,t-1) $+\beta 1((\Delta R E V i t-$ $\Delta R E C i t) / T A i, t-1)+\beta 2($ PPEit $/ T A i, t-1)+i t$ ..............................................(1)

2) Koefisien yang diperoleh dari hasil persamaan regresi berganda (1) kemudian dimasukkan kembali ke persamaan tersebut untuk menentukan besarnya nilai non-discretionary accruals yang akan digunakan untuk menghitung discretionary 
accruals (sebagai proksi manajemen laba).

3) Setelah nilai non-discretionary accruals diperoleh, kemudian total accruals dikurangi dengan non-discretionary accruals untuk memperoleh nilai discretionary accruals sebelum dan sesudah penerapan PSAK konvergensi IFRS.

4) Menghitung rata-rata nilai discretionary accruals masing-masing populasi sasaran $(\mu 1$ dan $\mu 2)$ sebelum dan sesudah penerapan PSAK konvergensi IFRS.

5) Membandingkan rata-rata nilai discretionary accruals masing-masing populasi sasaran $(\mu 1$ dan $\mu 2)$ sebelum dan sesudah penerapan PSAK konvergensi IFRS.

b. Rancangan Pengujian Hipotesis

Rancangan pengujian hipotesis penelitian ini adalah sebagai berikut:

$\mathrm{H}_{0}: \mu 2 \geq \mu 1$

Manajemen laba sesudah penerapan PSAK konvergensi IFRS tidak lebih rendah dibandingkan dengan manajemen laba sebelum penerapan PSAK konvergensi IFRS.

Ha : $\mu 2<\mu 1$

Manajemen laba sesudah penerapan PSAK konvergensi IFRS lebih rendah dibandingkan dengan manajemen laba sebelum penerapan PSAK konvergensi IFRS.

Dimana:

$\mu 1$ = Rata-rata manajemen laba sebelum penerapan PSAK konvergensi IFRS.

$\mu 2=$ Rata-rata manajemen laba sesudah penerapan PSAK konvergensi IFRS.

H0 diterima artinya manajemen laba sesudah penerapan PSAK konvergensi IFRS tidak lebih rendah dibandingkan dengan manajemen laba sebelum penerapan PSAK konvergensi IFRS. Ha diterima artinya manajemen laba sesudah penerapan PSAK konvergensi IFRS lebih rendah dibandingkan dengan manajemen laba sebelum penerapan PSAK konvergensi IFRS.

\section{HASIL DAN PEMBAHASAN}

\section{Deskripsi Data}

Dalam penelitian ini hanya terdapat satu variabel yaitu manajemen laba yang diukur dengan discretionary accruals absolut menggunakan Jones Modified Model yang dikembangkan oleh (Dechow P., Sloan R., 1995).

Deskripsi variabel penelitian yang mencakup nilai ratarata, maksimum, minimum dan standar deviasi ditampilkan pada Tabel.
Tabel 1 Deskripsi Data

\begin{tabular}{lccccc}
\hline & $\mathrm{N}$ & Min. & Max. & Mean & Std. Dev \\
\hline $\begin{array}{l}\text { Discretionary } \\
\text { Accruals Tahun } 10\end{array}$ & 0.055 & 0.517 & 0.26750 & 0.144575 \\
2010 & & & & & \\
$\begin{array}{l}\text { Discretionary } \\
\text { Accruals Tahun } 10\end{array}$ & 0.001 & 0.460 & 0.19610 & 0.140167 \\
2011 & & & & & \\
Valid N (listwise) & 10 & & & & \\
\hline Sumber: SPSS Output & & & & \\
\end{tabular}

Berdasarkan Tabel 1 dapat diketahui bahwa variabel discretionary accruals memiliki nilai minimum pada tahun 2010 dan 2011 berturut-turut sebesar 0,055 dan 0,001 yang berarti bahwa nilai discretionary accruals terendah masing-masing tahun berturut-turut sebesar 5,5\% dan $0,1 \%$ dari total aset, terjadi pada PT. Tambang Batubara Bukit Asam Tbk (PTBA). Nilai maksimum discretionary accruals sebesar 0,517 pada tahun 2010 dan 0,460 pada tahun 2011 yang berarti bahwa nilai discretionary accruals tertinggi masingmasing tahun berturut-turut sebesar $5,17 \%$ dan $4,6 \%$ dari total aset, terjadi pada PT. International Nickel Indonesia Tbk (INCO).

Rata-rata nilai discretionary accruals pada tahun 2010 dan 2011 berturut-turut sebesar 0,26750 dan 0,19590 yang berarti bahwa rata-rata manjemen laba yang dilakukan oleh perusahaan top leadings in market capitalization masing-masing tahun berturut-turut sebesar $26,75 \%$ dan $19,6 \%$ dari total aset dengan standar deviasi pada tahun 2010 dan 2011 berturutturut sebesar 0,1446 dan 0,1405 atau sebesar 14,46\% dan $14,05 \%$ dari total aset. Pada tahun 2010 dan tahun 2011 standar deviasi lebih rendah dari nilai rata-rata. Hal ini berarti sebaran data yang digunakan dalam penelitian ini bersifat homogen.

Nilai discretionary accruals yang bernilai positif menunjukkan bahwa terdapat discretionary accruals yang bersifat menaikkan laba (income increasing), sedangkan nilai discretionary accruals yang bernilai negatif menunjukkan bahwa terdapat discretionary accruals yang bersifat menurunkan laba (income minimizing). Oleh karena itu, nilai discretionary accruals diabsolutkan agar tidak mempengaruhi nilai rata-rata data. Rata-rata discretionary accruals tahun 2010 dan 2011 memiliki perbedaan, dimana rata-rata discretionary accruals tahun 2010 lebih tinggi dari rata-rata discretionary accruals tahun 2011. Ini menunjukkan bahwa perusahaan top leadings in market capitalization mengurangi praktik manajemen laba setelah penerapan PSAK konvergensi IFRS.

\section{Uji Hipotesis}

a. Perhitungan Discretionary Accruals Periode Sebelum Penerapan PSAK Konvergensi IFRS 
Langkah pertama yang dilakukan adalah menghitung nilai total accruals dengan cara menghitung selisih laba bersih dengan arus kas operasi. Nilai total accruals dijadikan sebagai variabel dependen. Kemudian dilakukan regresi untuk menentukan nilai estimasi dari non-discretionary accruals menggunakan Jones Modified Model yang dikembangkan oleh (Dechow P., Sloan R., 1995). Oleh karena itu, model persamaan regresi berganda yang digunakan untuk menentukan nilai estimasi dari nondiscretionary accruals sebagai berikut:

\section{TACCit/TAi,t-1 $=(1 / T A i, t-1)+\beta 1((\Delta R E V i t-$ $\Delta$ RECit $) / T A i, t-1)+\beta 2($ PPEit/TAi,t-1) $+i t$}

Hasil pengujian persamaan regresi berganda tersebut ditampilkan pada Tabel 2.

Tabel 2 Estimasi Non-discretionary accruals Periode Sebelum Penerapan PSAK Konvergensi IFRS

\begin{tabular}{|c|c|c|c|}
\hline \multicolumn{4}{|c|}{ Coefficients $^{\mathrm{a}}$} \\
\hline \multirow[t]{2}{*}{ Model } & \multicolumn{2}{|c|}{$\begin{array}{c}\text { Unstandardized } \\
\text { Coefficients }\end{array}$} & $\begin{array}{c}\text { Standardized } \\
\text { Coefficients }\end{array}$ \\
\hline & $\mathrm{B}$ & Std. Error & Beta \\
\hline 11 (Constant) & 0.101 & 0.082 & \\
\hline 1/TAi,t-1 & $-6.677 \mathrm{E} 11$ & $6.132 \mathrm{E} 11$ & -0.395 \\
\hline $\begin{array}{l}(\triangle \mathrm{REVit}- \\
\Delta \mathrm{RECit}) / \mathrm{TAi}, \mathrm{t}-1\end{array}$ & -0.072 & 0.209 & -0.123 \\
\hline PPEit/TAi,t-1 & -0.091 & 0.075 & -0.452 \\
\hline
\end{tabular}

a. Dependent Variable: TACCit/TAi,t-1

Sumber: SPSS Output

Koefisien yang diperoleh dari hasil regresi pada Tabel 2 digunakan untuk menentukan besarnya nilai nondiscretionary accruals yang akan digunakan untuk menghitung discretionary accruals. Oleh karena itu, Jones Modified Model sebelum perusahaan menerapkan PSAK konvergensi IFRS dapat ditulis kembali sebagai berikut:

TACCit/TAi,t-1 = - 0.395(1/TAi,t-1) - 0.123((DREVit$\Delta$ RECit)/TAi,t-1) - 0.452(PPEit/TAi,t-1) + it

Hasil perhitungan dari persamaan tersebut diperoleh nilai non-discretionary accruals, kemudian total accruals dikurangi dengan non-discretionary accruals untuk memperoleh nilai discretionary accruals sebelum penerapan PSAK konvergensi IFRS.

b. Perhitungan Discretionary Accruals Periode Sesudah Penerapan PSAK Konvergensi IFRS Seperti yang dilakukan pada tahap sebelum penerapan PSAK konvergensi IFRS, terlebih dahulu dilakukan regresi untuk menentukan nilai estimasi dari nondiscretionary accruals dengan persamaan sebagai berikut:

TACCit/TAi,t-1 $=(1 /$ TAi,t-1) $+\beta 1((\Delta R E V i t-$ $\Delta R E C i t) / T A i, t-1)+\beta 2(P P E i t / T A i, t-1)+i t$

Hasil pengujian regresi berganda tersebut disajikan pada Tabel 3 .

Koefisien yang diperoleh dari hasil regresi pada Tabel
3 digunakan untuk menentukan besarnya nilai nondiscretionary accruals yang akan digunakan untuk menghitung nilai discretionary accruals. Oleh karena itu, Modified Jones Model dapat ditulis kembali sebagai berikut:

TACCit/TAi,t-1 $=-0.537(1 /$ TAi,t-1) $+0.131((\Delta R E V i t-$ $\Delta$ RECit)/TAi,t-1) - 0.335(PPEit/TAi,t-1) + it

Hasil perhitungan dari persamaan tersebut diperoleh nilai non-discretionary accruals, kemudian total accruals dikurangi dengan non- discretionary accruals untuk memperoleh nilai discretionary accruals sesudah penerapan PSAK konvergensi IFRS.

Tabel 3 Estimasi Non-discretionary accruals Periode Sesudah Penerapan PSAK Konvergensi IFRS

\begin{tabular}{cccc}
\multicolumn{4}{c}{ Coefficients $^{a}$} \\
\hline \multicolumn{4}{c}{ Unstandardized } \\
Model & Coefficients & $\begin{array}{c}\text { Standardized } \\
\text { Coefficients }\end{array}$ \\
& B & Std. Error & Beta \\
\hline $\begin{array}{c}\text { (Constant }) \\
\text { 1/TAi,t-1 }\end{array}$ & 0.127 & 0.097 & \\
$(\Delta$ REVit- & $-1.137 \mathrm{E} 12$ & $9.870 \mathrm{E} 11$ & -0.537 \\
$\Delta$ RECit)/TAi,t-1 & 0.051 & 0.179 & 0.131 \\
PPEit/TAi,t-1 & -0.068 & 0.079 & -0.335 \\
\hline
\end{tabular}

a. Dependent Variable: TACCit/TAi,t-1

Sumber: SPSS Output

c. Uji Beda Rata-Rata Berpasangan

Setelah melakukan perhitungan total accruals, kemudian dilakukan pengujian regresi untuk menentukan nilai non-discretionary accruals, selanjutnya menghitung selisih total accruals dengan nilai non-discretionary accruals, maka diperoleh nilai discretionary accruals yang akan digunakan sebagai ukuran manajemen laba. Hipotesis yang diajukan menyatakan bahwa manajemen laba sesudah penerapan PSAK konvergensi IFRS lebih rendah dibandingkan dengan manajemen laba sebelum penerapan PSAK konvergensi IFRS.

Hipotesis tersebut diuji dengan membandingkan tingkat discretionary accruals sebelum dan sesudah penerapan PSAK konvergensi IFRS. Untuk itu peneliti membagi populasi sasaran menjadi dua kelompok, yaitu kelompok sebelum dan sesudah penerapan PSAK konvergensi IFRS. Pengujian hipotesis tidak memerlukan alat uji-t (uji signifikansi) karena penelitian ini menggunakan metode sensus dimana semua elemen populasi sasaran diteliti. Kesimpulan langsung diambil dari nilai rata-rata populasi sasaran $(\mu)$.

Nilai discretionary accruals sebelum dan sesudah penerapan PSAK konvergensi IFRS ditampilkan pada berikut ini :. 
Tabel 4 Nilai Discretionary Accruals Sebelum dan Sesudah Penerapan PSAK konvergensi IFRS

\begin{tabular}{|c|c|c|c|}
\hline \multirow[b]{2}{*}{ No } & \multirow[b]{2}{*}{$\begin{array}{c}\text { Kode } \\
\text { Emiten }\end{array}$} & \multicolumn{2}{|c|}{ Discretionary Accruals } \\
\hline & & $\begin{array}{c}\text { Sebelum } \\
\text { Penerapan } \\
\text { PSAK } \\
\text { Konvergensi } \\
\text { IFRS (2010) } \\
\end{array}$ & $\begin{array}{c}\text { Sesudah } \\
\text { Penerapan } \\
\text { PSAK } \\
\text { Konvergensi } \\
\text { IFRS (2011) } \\
\end{array}$ \\
\hline 1 & AALI & 0.145 & 0.088 \\
\hline 2 & ADRO & 0.225 & 0.184 \\
\hline 3 & ANTM & 0.250 & 0.197 \\
\hline 4 & BYAN & 0.267 & 0.180 \\
\hline 5 & GGRM & 0.290 & 0.309 \\
\hline 6 & INCO & 0.517 & 0.460 \\
\hline 7 & ITMG & 0.220 & 0.100 \\
\hline 8 & LPKR & 0.201 & 0.091 \\
\hline 9 & PTBA & 0.055 & 0.001 \\
\hline 10 & SMGR & 0.505 & 0.351 \\
\hline \multicolumn{2}{|c|}{ Rata-Rata $(\mu)$} & $0.267\left(\mu_{1}\right)$ & $0.196\left(\mu_{2}\right)$ \\
\hline
\end{tabular}

Sumber: Data diolah (2013)

Penelitian ini melakukan uji beda rata-rata berpasangan untuk menguji hipotesis secara empiris. Variabel yang diuji adalah discretionary accruals tahun sebelum penerapan PSAK konvergensi IFRS (tahun 2010) dan tahun sesudah penerapan PSAK konvergensi IFRS (tahun 2011).

Rata-rata discretionary accruals pada periode sebelum penerapan PSAK konvergensi IFRS memiliki nilai sebesar $0,26750(26,75 \%$ dari total aset) yang relatif lebih tinggi dari rata-rata discretionary accruals periode sesudah penerapan PSAK konvergensi IFRS yang memiliki nilai sebesar $0,19610(19,6 \%$ dari total aset).

Hipotesis alternatif (Ha) yang diajukan bahwa manajemen laba sesudah penerapan PSAK konvergensi IFRS lebih rendah dibandingkan dengan manajemen laba sebelum penerapan PSAK konvergensi IFRS dapat diterima. Ini artinya menolak hipotesis nol (H0) yang menyatakan bahwa manajemen laba sesudah penerapan PSAK konvergensi IFRS tidak lebih rendah dibandingkan dengan manajemen laba sebelum penerapan PSAK konvergensi IFRS.

Hasil pengujian tersebut memberi bukti empiris bahwa penerapan PSAK konvergensi IFRS relatif efektif bagi perusahaan yang termasuk 50 top leadings in market capitalization yang terdaftar di BEI tahun 2011 untuk mengurangi tingkat manajemen laba.

Berdasarkan hasil penelitian ini perusahaan cenderung menerapkan metode dan kebijakan akuntansi sesuai dengan PSAK konvergensi IFRS, sehingga laporan keuangan, khususnya informasi laba menjadi lebih berkualitas dibandingkan periode sebelum penerapan PSAK konvergensi IFRS. Hal ini mungkin dikarenakan penerapan PSAK konvergensi IFRS masih tergolong baru bagi dunia usaha di Indonesia, sehingga keinginan perusahaan untuk mencoba menerapkan PSAK konvergensi IFRS secara baik dan benar lebih tinggi. Dengan demikian perusahaan dapat merasakan dampak yang signifikan dari perubahan standar akuntansi, yakni perubahan dari PSAK ke PSAK konvergensi IFRS. Selain itu, mungkin hal tersebut terjadi karena para manajer perusahaan di Indonesia telah menyadari pentingnya menerapkan PSAK konvergensi IFRS secara efektif dan efisien demi keberlangsungan perusahaan, baik di masa sekarang maupun di masa yang akan datang.

Hasil penelitian ini konsisten dengan penelitian Asbaugh dan Pincus (2001) yang menyatakan bahwa kualitas laba setelah penerapan IAS oleh perusahaan non-US lebih tinggi dibandingkan sebelum penerapan IAS, sehingga keakuratan prediksi analis terhadap laba perusahaan semakin meningkat.

Penelitian ini hasilnya juga konsisten dengan penelitian (Barth, M. E., W. R. Landsman, 2008) yang menunjukkan bahwa setelah diperkenalkannya IAS, tingkat manajemen laba menjadi lebih rendah, relevansi nilai menjadi lebih tinggi, dan pengakuan kerugian menjadi semakin tepat waktu, dibandingkan dengan masa sebelum transisi di mana akuntansi masih berdasarkan local GAAP. Hal yang sama juga telah dibuktikan oleh (C. Leuz \& Verrecchia, 2000); (Christian Leuz, 2003); dan Christensen, Lee, dan Walker (2008).

Hasil penelitian ini tidak konsisten dengan hasil penelitian (Rudra \& A, 2012) yang menunjukkan bahwa perusahaan publik di India yang mengadopsi IFRS lebih suka meratakan laba dibandingkan dengan perusahaan yang tidak mengadopsi IFRS

Hal yang sama juga telah dibuktikan oleh ( Kieso, T., 2008) yang meneliti dampak keharusan mengadopsi IFRS terhadap manajemen laba pada 1.146 perusahaan di Australia, Prancis, dan UK mulai tahun 2005 hingga 2006. Penelitian tersebut menemukan bukti bahwa manajemen laba di negara-negara tersebut tidak mengalami penurunan setelah adanya keharusan mengadopsi IFRS, dan bahkan meningkat untuk Prancis.

\section{KESIMPULAN}

Berdasarkan hasil penelitian dapat ditarik kesimpulan bahwa manajemen laba sesudah penerapan PSAK konvergensi IFRS lebih rendah dibandingkan dengan manajemen laba sebelum penerapan PSAK konvergensi IFRS pada perusahaan top leadings in market capitalization yang terdaftar di Bursa Efek Indonesia tahun 2010-2011. Artinya, hasil penelitian ini menerima hipotesis yang diajukan. 
Dengan demikian, kualitas laba perusahaan top leadings in market capitalization yang terdaftar di Bursa Efek Indonesia periode sesudah penerapan PSAK konvergensi IFRS meningkat dibandingkan periode sebelum penerapan PSAK konvergensi IFRS.

\section{REFERENSI}

Avianti, I. (2006). Mengungkapkan Praktik Earning Management di Perusahaan. Jurnal Bisnis, Manajemen, Ekonomi, 7(3), 828-841.

Barth, M. E., W. R. Landsman, \& M. H. L. (2008). International Accounting Standards and Accounting Quality. Journal of Accounting Research, 46, 467-498.

Chariri, Anis, \& S. K. S. H. (2010). Menguji Kualitas Standar Akuntansi Hasil Adopsi IFRS: Studi Empiris pada PSAK No. 55. Simposium Nasional Akuntansi Ke 13. Universitas Jendral Soedirman.

Copeland, R. M. (1968). Income Smoothing. Journal of Accounting Research, 6, 101-116.

Daske, H., \& G. G. (2006). International Financial Reporting Standards and Experts' Perceptions of Disclosure Quality. Abacus, 42, : 461-498.

Dechow P., Sloan R., \& S. A. (1995). Detecting Earnings management. The Accounting Review, 70, 193-225.

Fischer, M., \& K. R. (1995). Attitudes of Students and Accounting Practitioners Concerning the Ethical Acceptability of Earnings management. Journal of Business Ethics, 14, 433-444.

Gontcharov, I., \& J. Z. (2007). Do Accounting Standards Influence the Level of Earnings management? Evidence from Germany.Die Unternehmung. Swiss Journal of Business Research and Practice, 61, 371-388.

Healy, P. M. (1985). The Effect of Bonus Schemes on Accounting Decisions. Journal of Accounting and Economics, 7, 85-107.

Jeanjean, T., \& H. S. (2008). Do Accounting Standards Matter? An Exploratory Analysis of Earnings management Before and After IFRS Adoption. Journal of Accounting and Public Policy, Vol. 27: 480-494, 27, 480-494.

Kieso, D. E., J. J. Weygandt, \& T. D. W. (2008). Intermediate Accounting (10th ed.). Jakarta: Erlangga.

Lantto, A. M. (2007). Does IFRS Improve the Usefulness of Accounting Information in CodeLaw Country. In IFRS. Law Country.

Lastansi. (2008). Element Research Design. In Metode Penelitian. Jakarta.

Lestari. (2010). Fenomena Earnings management Sebagai Sebuah Kecurangan. Akuntansi, 1, 115.

Leuz, C. (2003). IAS Versus U.S. GAAP:
Information Asymmetry-Based Evidence from Germany's New Market. Journal of Accounting Research, 41, 445-472.

Leuz, C., \& Verrecchia, R. E. (2000). The Economic Consequences of Increased Disclosure. Journal of Accounting Research, 38, 91-124.

Levitt, C. A. (1998). The Numbers Game. The CPA Jozitnal, 68, 14-19.

Nugroho, G. A. (2011). Pengaruh Struktur Kepemilikan dan Leverage Terhadap Earning Management pada Perusahaan yang Melakukan IPO di Bursa Efek Indonesia. Diponegoro.

Petreski, M. (2006). The Impact of International Accounting Standards on Firms. In International Accounting Standards.

Rohaeni, D., \& T. A. (2012). Tanpa Tahun. Pengaruh Konvergensi IFRS terhadap Income Smoothing dengan Kualitas Audit sebagai Variabel Moderasi. Simposium Nasional Akuntansi XV. Retrieved from http://sna.akuntansi.unikal.ac.id/makalah/100SIPE-22.pdf

Rudra, T., \& A, C. (2012). Does IFRS Influencing Earnings management? Evidence from India. Journal of Management Research, 4, 1-13.

Rusmanto, D. (2011). Kapitalisasi Pasar (Market Capitalization). Retrieved March 19, 2013, from INFOACEH website: http://infoaceh.com

Sarlina Sari. (2019). Analisis Perbedaan Manajemen Laba Sebelum dan Sesudah Penerapan PSAK Konvergensi IFRS. Moneter, 6(1), 13-22.

Schipper, K. (1989). Commentary on Earnings management. Accounting Horizons, 3, 89-102.

Scott, W. R. (2006). Financial Accounting Theory (4th ed.). Toronto: Pearson Education Canada, Inc.

Situmorang, M. A. S. (2011). Transisi Menuju IFRS dan Dampaknya Terhadap Laporan Keuangan (Studi Empiris pada Perusahaan yang Listing di BEI). Diponegoro.

Widyaningdyah, A. U. (2001). Analisis FaktorFaktor yang Berpengaruh Terhadap Earnings management pada Perusahaan Go Public di Indonesia. Jurnal Akuntansi \& Keuangan, 3(2), 89-101. 


\section{PROFIL PENULIS}

Sarlina Sari yang lahir di Beungga pada tanggal 3 Agustus 1990 merupakan seorang tenaga pengajar di Universitas Bina Sarana Informatika Jakarta bidang sains akuntansi sekaligus direktur Penerbit CV. Bunda Ratu. Ia ahli di bidang akuntansi dan keuangan dan juga telah menulis beberapa buku referensi di bidang akuntansi dan perpajakan.

Sarlina Sari merupakan alumni Univeristas Syiah
Kuala dan Universitas Indonesia. Ia pernah memperoleh penghargaan sebagai mahasiswa terbaik pada Program Studi Ekonomi Akuntansi sekaligus pada Fakultas Ekonomi Universitas Syiah Kuala. Selain itu, ia juga memperoleh predikat cumlaude pada jenjang sarjana dan magister. Ia berasal dari Aceh dan berdomisili di Jakarta. 